Wagner Marcenes 1

\title{
The relationship between dental status, food selection, nutrient intake, nutritional status, and body mass index in older people
}

\author{
A relação entre estado dentário, seleção alimentar, \\ ingestão de nutrientes, estado nutricional e índice \\ de massa corporal em idosos
}

Jimmy George Steele 2

Aubrey Sheiham 1

Angus Willian Gilmour Walls 2

\footnotetext{
1 Department of Epidemiology and Public Health, University College London Medical School, 1-19 Torrington Place, London WC1E 6BT, United Kingdom. 2 School of Dental Sciences, University of Newcastle Upon Tyne. Framlington Place, Newcastle upon Tyne,
} NE2 4BW, United Kingdom.

\begin{abstract}
This paper reviewed the findings from a national survey in Great Britain which assessed whether dental status affected older people's food selection, nutrient intake, and nutritional status. The survey analyzed national random samples of free-living and institution subjects for dental examination, interview, and four-day food diary as well as blood and urine tests In the free-living sample, intakes of non-starch polysaccharides, protein, calcium, non-heme iron, niacin, and vitamin $C$ were significantly lower in edentulous as compared to dentate subjects. People with 21 or more teeth consumed more of most nutrients, particularly non-starch polysaccharides. This relationship in intake was not apparent in the hematological analysis. Plasma ascorbate and retinol were the only analytes significantly associated with dental status. Having 21 or more teeth increased the likelihood of having an acceptable body mass index (BMI). Thus, maintaining a natural and functional dentition defined as having more than twenty teeth into old age plays an important role in having a healthy diet rich in fruits and vegetables, a satisfactory nutritional status, and an acceptable BMI.
\end{abstract}

Key words Aging Health; Oral Health; Nutrition; Body Mass Index

Resumo Este artigo objetivou revisar os achados do levantamento epidemiológico conduzido no Reino Unido, cuja finalidade foi avaliar a relação entre saúde bucal, ingestão de nutrientes e estado nutricional. Uma amostra representativa dos idosos institucionalizados e não-institucionalizados foi examinada em relação à saúde bucal. Além disso, amostras de sangue e urina foram coletadas e entrevistou-se os idosos, ocasião em que se completou um diário alimentar de quatro dias. Na amostra de idosos não-institucionalizados, o consumo de polissacarídeos nãoamido (fibras), proteína, cálcio, ferro nao-hemoglobina, niacina e vitamina $C$ foi significantemente menor em edêntulos do que em não-edêntulos. Idosos com a presença de 21 dentes ou mais consumiram mais nutrientes, principalmente fibras. Ácido ascórbico e retinol plasmático estavam significantemente associados com saúde bucal. Concluiu-se que manter uma dentição natural funcional, definida como ter 21 dentes ou mais, desempenha um importante papel em ter uma dieta saudável rica em frutas, verduras e legumes, um estado nutricional satisfatório e um Índice de Massa Corporal aceitável.

Palavras-chave Saúde do Idoso; Saúde Bucal; Nutrição; Índice de Massa Corporal 


\section{Introduction}

Oral health status may be a particularly important factor for the nutrition of older people. There is some evidence that impaired dentition can affect individuals by causing dietary restrictions via difficulty in chewing, possibly compromising their nutritional status and wellbeing (Chauncey, et al., 1984; Hollister \& Weintraub, 1993; Papas et al., 1989). Tooth loss has been associated with changes in food preference and nutritional deficiency in older people (Brodeur et al., 1993; Carlos \& Wolfe, 1989; Chauncey et al., 1984; Krall, 1998; Moynihan et al., 1994; Wayler et al., 1984). This may be because people who cannot chew or bite comfortably are less likely to consume high-fiber foods such as bread, fruit, and vegetables, thereby risking reducing their intake of essential nutrients (Brodeur et al., 1993).

Older people are particularly vulnerable to dietary restrictions with possible consequences for their nutritional status because they tend to have fewer natural teeth. Despite their potential significance, there are remarkably few data from studies on large populations that tested whether or not the number and condition of teeth influence the choice of food, diet, and nutrition. In a comprehensive review of the nutritional effects of tooth loss, Geissler \& Bates (1984) reported that the quality of evidence was not good, suffering from various methodological shortcomings. Further studies consistently demonstrated a relationship between the two factors, but subsequent reviews have concluded that good evidence remains scarce (Moynihan, 1995; Papas et al., 1998). The existing evidence linking oral health and nutrition has tended to present shortcomings such as the samples were small and insufficiently representative and there were difficulties in terms of data collection or analysis.

The aim of this paper is to review the major findings from a large representative and comprehensive national survey in Great Britain (Steele et al., 1998) which assessed the degree to which the numbers of teeth and dentures affected older people's ease of eating, nutrient intake, nutritional status, and body mass index (BMI).

\section{Methods}

The oral health survey of people participating in the British National Diet and Nutrition Survey (NDNS) of adults aged 65 and over used two separate population samples living in Great
Britain. The first was a representative sample of the people aged 65 and over living in the community, hereafter called the free-living sample. The second was a representative sample of adults aged 65 years and over who were in residential care, hereafter called the institution sample (Finch et al., 1998). All subjects gave informed consent. The Medical Research Ethics Committees approved the study protocol.

Sampling strategies were different for the two groups, so they have been kept separate when reporting the data. Weighting was used to correct for stratification of the sample and biases within the sample resulting from known systematic error. Complete details of sampling and weighting procedures are published elsewhere (Finch et al., 1998; Steele et al., 1998).

The dental examination recorded the distribution of natural teeth, the total number of occluding natural pairs of teeth, spaces, and partial dentures and detailed information about the condition of teeth. The questionnaire comprised 50 questions and was used to record a wide range of social, socio-dental, and behavioral variables including the effect of dentition on food choice. Full details are published elsewhere (Steele et al., 1998).

The dietary survey collected information about the quantities of foods and nutrients consumed by the sample of elderly people, as well as demographic data, anthropometric measurements, and measurements of certain nutrients in blood and urine. To measure body fatness, height and weight measurements were used to derive the Quetelet or body mass index, a ratio calculated by reference to the weight in kilograms and the height in meters squared (weight $[\mathrm{kg}] /$ height $[\mathrm{m}]^{2}$ ) Height was measured with a portable, digital telescopic stadiometer, participants being measured without their shoes and head horizontal in the Frankfurt Plane. Weight was measured to the nearest 100 grams using Soehnle Quantratonic digital personal scales on a hard, level surface (Finch et al., 1998). Demi-span, which is the distance between the sternal notch and the finger roots with the arm outstretched laterally, was used as an alternative measure of skeletal size when appropriate. Height measurements may be difficult or inaccurate for people who are unable to stand straight. Furthermore, most people lose height as vertebrae and discs compress with age. The internationally agreed threshold of acceptable BMI (20-25), underweight $(<20)$, overweight (25-30), and obese ( $>30$ ) were adopted.

Detailed information about the quantities of foods and nutrients consumed were collected. Participants or their carers were asked to 
keep a four-day weighed diary record of all food and drink consumed both in and out of the home. Data from this were converted to nutritional intake data using standard methodologies (Finch et al., 1998). The intake data have been corrected to eliminate high levels of micronutrient intake associated with prescribed nutrient supplements. Blood and urine were collected by trained nurses and analyzed by the Micronutrient Status Laboratory, formerly at the Medical Research Council Dunn Nutrition Unit, Cambridge.

Participants who agreed to give blood were asked to fast from midnight the day before nurses visited early next morning. For certain assays, external quality assurance schemes were operated. There was no identifiable bias according to agreement to give a blood sample. Full details are given in Finch et al. (1998).

The data presented are the results of analysis comparing both intake data and blood analytes for selected nutrients with a range of measures of dental health. The nutrients were those likely to have been affected by the reported restrictions in food consumption and nutrient intakes (Steele et al., 1998).

Relationships between dental health status and nutritional status may be confounded by age. Rates of edentulousness increase, while some hematological and biochemical markers of nutritional status decrease with increasing age. To make allowance for this and other key confounding factors, a limited logistic multivariate analysis has been undertaken in all cases to control for the potential confounding effects of age, sex, social class, and region of residence, irrespective of their statistical significance. Regression coefficients for the variables: "number of natural teeth" and "number of posterior occluding pairs" were estimated based on a continuous scale. Sex, social class, region of residence, partial denture-wearing, and dental status were entered into the equation as binary (dummy) variables. Assumptions of normality, linearity, and equality of variances were tested. Log (10) transformation was performed where there was deviation from normality. Statistical significance was set at the $5 \%$ level and the term "not statistically significant" indicates $\mathrm{P}<0.05$.

\section{Results}

The sample for the oral health survey was drawn from those who completed the four-day weighed dietary record, representing $59 \%$ of the issued sample for the dietary survey. After correction for sub-sampling of the edentulous group, but before the application of sample weights, $69 \%$ of the food diary sample took part in the oral health survey. For the institution group, $67 \%$ (unweighted) of the food diary group remained in the sample undergoing dental examination. In total, 407 dentate and 346 edentulous participants were examined in the free-living group. In the institution group there were 57 dentate and 139 edentulous participants. Further details of response rate can be found in Finch et al. (1998) and Steele et al. (1998). The results presented here refer to the free-living group.

\section{Free-living group - difficulty eating} specified foods

Among the edentulous, $50 \%$ had difficulty eating or could not eat apples at all. Nuts (42\%), raw carrots $(41 \%)$, well-done steaks $(33 \%)$, tomatoes $(20 \%)$, and lettuce $(17 \%)$ were also difficult to eat for many edentulous individuals, and nearly one in five edentulous participants said that they could not eat raw carrots or nuts at all. Smaller percentages of edentulous individuals also said that they could not eat apples $(12 \%)$, well-done steaks $(8 \%)$, potato chips $(4 \%)$, lettuce $(4 \%)$, oranges $(3 \%)$, and tomatoes (2\%) at all. When compared with dentate individuals, the edentulous had significantly greater difficulty in eating tomatoes, raw carrots, apples, nuts $(\mathrm{p}<0.001)$, lettuce, and well-done steaks $(p<0.01)$ after statistical correction for the confounding affects of age, sex, social class, and region of origin (Table 1).

Among people with teeth, the number of natural teeth significantly affected the ability to eat some foods. Apples were a particularly good example: $45 \%$ of people with 1-10 teeth had some difficulty eating them or could not eat them at all, whereas only $12 \%$ of those with 21 or more teeth had the same limitation. All people with 21 or more teeth could eat sliced bread, cheese, tomatoes, roast potatoes, and cooked greens easily, and $86 \%$ or more could eat with ease all of the other foods listed. The odds ratios were 0.9 for the relationships between number of teeth and foods such as raw carrots, apples, nuts ( $\mathrm{p}<0.001)$, and well-done steaks and potato chips $(\mathrm{p}<0.05)$ after correction for confounding variables (Table 2 ).

Free-living group - nutrient intake

Edentulous individuals had significantly lower intakes of non-starch polysaccharides (fiber), intrinsic and milk sugars $(\mathrm{p}<0.001)$, protein, 
Table 1

Percent of participants who reported that they could eat only with some difficulty or could not eat some at all various types of food, analyzed by dental status; free-living group.

\begin{tabular}{|c|c|c|c|}
\hline Type of food & $\%$ Dentate & $\%$ Edentulous & Odds ratio $(\mathrm{Cl})^{a, b}$ \\
\hline Weighted base & 418 & 287 & \\
\hline Tomatoes & $3 c$ & 20 & $3.6(2.42-5.51) * \star \star$ \\
\hline Raw carrots & 19 & 41 & $2.0(1.35-3.07)$ *** \\
\hline Roast potatoes & 3 & 8 & $1.1(0.45-2.95) \mathrm{ns}$ \\
\hline Lettuce & 4 & 17 & $1.9(0.99-3.62) \mathrm{ns}$ \\
\hline Well-done steaks & 20 & 33 & $1.7(1.10-2.61)$ * \\
\hline Apples & 28 & 50 & $1.6(1.10-2.32) * \star \star$ \\
\hline Oranges & 4 & 11 & $1.3(0.64-2.84) \mathrm{ns}$ \\
\hline Nuts & 24 & 42 & $1.5(1.03-2.22) * \star \star$ \\
\hline Potato chips & 5 & 10 & $1.0(0.50-2.02) \mathrm{ns}$ \\
\hline
\end{tabular}

ns $=p>0.05$

${ }^{\star} \mathrm{p}<0.05 ;{ }^{\star \star} \mathrm{p}<0.01 ; * \star \star \mathrm{p}<0.001$

a Odds ratio and significance level refer to unweighted data.

b Adjusted for age, sex, social class, and region of residence.

c Percentages refer to weighted data. tors were taken into account. There were large and statistically significant differences between dentate and edentulous individuals for mean plasma ascorbate level ( $p<0.05)$, and a significant trend according to the number of teeth and posterior occluding pairs of teeth ( $p$ $<0.01$ ) (Table 4). The ascorbate values for the edentulous were around $20 \%$ lower than for the dentate $(49 \mu \mathrm{mol} / \mathrm{l}$ against $40 \mu \mathrm{mol} / \mathrm{l})$. Plasma retinol was also significantly lower in the edentulous than the dentate $(\mathrm{p}<0.01)$, but this was not significantly related to both numbers of teeth and posterior occluding pairs of teeth after confounding factors had been controlled (Table 4).

\section{Free-living group - body mass index}

The majority of the sample had a BMI greater than $25 ; 47.4 \%$ were overweight and $18.9 \%$ were obese. Few people were underweight (3.8\%), and $29.9 \%$ were in the "normal" category. Frequency distribution of BMI categories was similar in dentate and edentulous people. People without teeth were significantly $(\mathrm{p}=0.05)$ more likely to be underweight than those with eleven or more teeth: $12.3 \%$ and $2.9 \%$ respectively (Table 5). Large differences in BMI were found between dentate people with 1-10 teeth (24\%) and those with more than ten teeth $(2.9 \%)(\mathrm{p}=$ 0.001 , Table 5). Dentate individuals with less than 21 natural teeth were on average more than 3 times more likely to be obese than those with 21-32 teeth ( $p=0.036$, Table 5$)$. There was no statistical difference in both the proportions of overweight and obese adults between those who were edentulous and those who were dentate with 21 or more teeth. A similar pattern was observed when another measure of oral health was used: number of posterior occluding pairs of teeth. All results were adjusted for the confounding effects of age, social class, region of origin, and partial denture-wearing.

\section{The institution sample}

Large percentages of people in residential care said they had difficulty eating some food items because of their teeth. Differences between dentate and edentulous individuals were often rather small in the institution sample, and there were no consistent trends or significant differences between the two. Comparing edentulous people living in residential care with edentulous individuals living in the community, the former were even more likely to report problems eating than their counterparts living in the community. In the institution sample, 53\% 
Percent of dentate participants who reported they could eat only with some difficulty or could not eat some at all various types of food, odds ratio, and statistical significance level analyzed by number of natural teeth; free-living group (weighted data).

\begin{tabular}{lrrrrr}
\hline Type of food & $\begin{array}{c}\text { \% 1-10 } \\
\text { teeth }\end{array}$ & $\begin{array}{c}\text { \% 11-20 } \\
\text { teeth }\end{array}$ & $\begin{array}{c}\text { \% 21+ } \\
\text { t teeth }\end{array}$ & $\begin{array}{c}\text { \% all } \\
\text { Dentate }\end{array}$ & Odds ratio (Cl)a \\
\hline Weighted baseb & 135 & 167 & 124 & 426 & \\
Tomatoes & 6 & 2 & 0 & 3 & $0.9(0.81-0.93)^{\star * *}$ \\
Raw carrots & 32 & 18 & 5 & 19 & $0.9(0.86-0.92)^{* * *}$ \\
Roast potatoes & 4 & 4 & 0 & 3 & $0.9(0.87-1.02) \mathrm{ns}$ \\
Lettuce & 8 & 2 & 0 & 4 & $0.9(0.87-0.98)^{\star *}$ \\
Well-done steaks & 25 & 22 & 14 & 20 & $0.9(0.91-0.97)^{\star * *}$ \\
Apples & 45 & 26 & 12 & 28 & $0.9(0.90-0.95)^{* * *}$ \\
Oranges & 7 & 1 & 4 & 4 & $0.9(0.88-0.99)^{*}$ \\
Nuts & 41 & 24 & 7 & 24 & $0.9(0.89-0.95)^{* * *}$ \\
Potato chips & 10 & 4 & 2 & 5 & $0.9(0.89-0.99)^{*}$ \\
\hline
\end{tabular}

$\mathrm{ns}=\mathrm{p}>0.05 ;{ }^{*} \mathrm{p}<0.05 ;{ }^{* *} \mathrm{p}<0.01,{ }^{* *} \mathrm{p}<0.001$

a Odds ratio and significance level refer to unweighted data.

b Percentages refer to weighted data.

Table 3

Daily intake of nutrients and linear regression coefficients, adjusted for age, sex, social class, region of residence, and partial denture wearing among participants, analyzed by dental status; free-living.

\begin{tabular}{|c|c|c|c|c|}
\hline Daily intake of nutrients & Dentate Mean & Edentulous Mean & $\begin{array}{l}\text { Regression Coefficient } \\
\qquad(95 \% \mathrm{Cl})\end{array}$ & Significance level \\
\hline Weighted basea & 418 & 287 & & \\
\hline Energy (Kcal) & 1,768 & 1,583 & $54.3(-12.2-120.9)$ & 0.11 \\
\hline Protein (g) & 68.0 & 60.1 & $3.4(0.9-5.8)$ & 0.007 \\
\hline Fat (g) & 69.0 & 63.9 & $1.1(-2.4-4.6)$ & 0.54 \\
\hline Total carbohydrate (g) & 217.0 & 195.0 & $6.6(-2.3-15.6)$ & 0.15 \\
\hline Intrinsic and milk sugars (g) & 43.0 & 34.0 & $4.7(2.2-7.2)$ & $<0.001$ \\
\hline Non-starch polysaccharide (g) & 14.0 & 11.0 & $2.7(1.6-3.8)$ & $<0.001$ \\
\hline Calcium (mg) & 834.0 & 722.0 & $56.6(12.9-100.3)$ & 0.01 \\
\hline Heme iron (mg) & $0.7(0.8) c$ & $0.6(0.71) c$ & $0.02 d(-0.03-0.20)$ & 0.49 \\
\hline Non-heme iron (mg) & 10.3 & 8.8 & $0.64(0.06-1.22)$ & 0.03 \\
\hline Thiamin (mg) & $2.3(1.4)$ & $1.3(1.2)$ & $0.08 d(0.01-0.14)$ & 0.03 \\
\hline Riboflavin (mg) & $2.6(1.6) \mathrm{c}$ & $1.5(1.3) \mathrm{c}$ & $0.10 \mathrm{~d}(0.03-0.16)$ & 0.002 \\
\hline Niacin equivalent (mg) & 32.0 & 27.0 & $2.0(0.4-3.6)$ & 0.01 \\
\hline Pantothenic Acid (mg) & $6.0(5.0) c$ & $4.0(4.0) \mathrm{c}$ & $0.09 d(0.03-0.15)$ & 0.003 \\
\hline Vitamin C (mg) & $81.0(6.0) c$ & $60.0(5.0) c$ & $0.07 d(0.02-0.12)$ & 0.006 \\
\hline Vitamin E (mg) & $14.0(8.0) c$ & $8.0(7.0) \mathrm{c}$ & $0.11 d(0.01-0.21)$ & 0.04 \\
\hline
\end{tabular}

a Means were calculated using weighted data.

b Linear regression analyses were carried out using unweighted data.

c Exponential of the mean and median of the log (10) values for daily intake of nutrients.

d Regression coefficients after log (10) transformation. 
Table 4

Hematological and biochemical indices and linear regression coefficients, adjusted for age, sex, social class, region of residence, and partial denture wearing among dentate participants, analyzed by dental status and number of teeth; free-living group.

\begin{tabular}{|c|c|c|c|c|c|}
\hline \multirow{2}{*}{$\begin{array}{l}\text { Hematological and } \\
\text { biochemical indices }\end{array}$} & \multicolumn{3}{|c|}{ Mean } & \multirow{2}{*}{$\begin{array}{l}\text { Regression coefficienta } \\
\qquad(95 \% \mathrm{Cl})\end{array}$} & \multirow[t]{2}{*}{$p$ value } \\
\hline & \multicolumn{2}{|c|}{ Dentate } & Edentate & & \\
\hline Weighted baseb & \multicolumn{2}{|c|}{309} & 199 & & \\
\hline $\begin{array}{l}\text { Plasma ascorbate } \\
(\text { vitamin C) }(\mu \mathrm{mol} / \mathrm{l}) \mathrm{c}\end{array}$ & \multicolumn{2}{|c|}{49} & 40 & $5.17(0.80,9.55)$ & 0.02 \\
\hline Plasma retinol $(\mu \mathrm{mol} / \mathrm{l}) \mathrm{d}$ & \multicolumn{2}{|c|}{$2.3(2.2) \mathrm{d}$} & $2.1(2.0) d$ & $0.030(0.009,0.052) c$ & 0.005 \\
\hline $\begin{array}{l}\text { Hematological and } \\
\text { biochemical indices }\end{array}$ & $1-10$ teeth & $11-20$ teeth & $21+t$ teeth & $\begin{array}{l}\text { Regression coefficienta } \\
\qquad(95 \% \mathrm{Cl})\end{array}$ & $p$ value \\
\hline Weighted basea & 93 & 120 & 97 & & \\
\hline $\begin{array}{l}\text { Plasma ascorbate } \\
\text { (vitamin C) (nmol/l)c }\end{array}$ & 46 & 49 & 53 & $0.65(0.18,1.12)$ & 0.008 \\
\hline Plasma retinol $(\mathrm{nmol} / \mathrm{l}) \mathrm{c}$ & $2.3(2.2)$ & $2.3(2.2)$ & $2.2(2.2)$ & $0.001(-0.001,0.003) c$ & 0.51 \\
\hline
\end{tabular}

a Linear regression analyses were carried out using unweighted data.

b Means were calculated using weighted data

c Regression coefficients after log (10) transformation.

$d$ Exponential of the mean and median of the log (10) values for daily intake of nutrients.

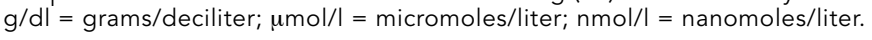

Table 5

Frequency distribution of body mass index (BMI) by number of teeth and odds ratio adjusted for age, sex, social class, region of residence, and partial denture wearing; in a sample of 629 free-living adults aged 65 or over in Great Britain (unweighted data).

\begin{tabular}{|c|c|c|c|c|}
\hline Number of teeth & Base & n (\%) & OR $(95 \% \mathrm{Cl})$ & p value \\
\hline \multicolumn{5}{|l|}{$\mathrm{BMI}<20$} \\
\hline Edentulous & 106 & 12.3 & & \\
\hline $11-32$ & 69 & 2.9 & & 0.0501 \\
\hline $1-10$ & 37 & 24.3 & & \\
\hline $11-32$ & 69 & 2.9 & & 0.0011 \\
\hline \multicolumn{5}{|l|}{$\mathrm{BMI}=25-30$} \\
\hline Edentulous & 220 & 57.7 & $1.2(0.54-2.51)$ & 0.7032 \\
\hline $1-10$ & 81 & 65.4 & $1.7(0.76-3.91)$ & 0.195 \\
\hline $11-20$ & 107 & 69.2 & $1.9(0.94-3.69)$ & 0.074 \\
\hline $21-32$ & 78 & $56.4 \%$ & 1 & \\
\hline \multicolumn{5}{|l|}{$\mathrm{BMI}>30$} \\
\hline Edentulous & 143 & 35.0 & $2.3(0.78-6.77)$ & 0.1292 \\
\hline $1-10$ & 51 & 45.1 & $3.1(1.08-8.84)$ & 0.036 \\
\hline $11-20$ & 65 & 49.2 & $3.3(1.29-8.22)$ & 0.012 \\
\hline $21-32$ & 48 & $29.2 \%$ & 1 & \\
\hline
\end{tabular}

1 Fisher's exact test

2 Multiple logistic regression 
of participants said they had problems eating or could not eat apples $50 \%$ in the free-living sample). There were larger differences for raw carrots (51\% against $41 \%$ ), well-done steak (50\% against $33 \%$ ), and nuts (57\% against $42 \%$ ). A number of foods such as nuts (35\%), raw carrots $(29 \%)$, apples $(24 \%)$, well-done steak (18\%), and lettuce $(6 \%)$ could not be eaten at all by people living in residential care (data for dentate and edentulous combined).

The mean intakes of most nutrients were lower in the institution sample than those found in the free-living sample except for carbohydrate, non-milk extrinsic sugars, and calcium, for which intake values were very similar. In the institution sample, there was little difference between dentate and edentulous subjects. Nutrient intake values for both were generally closest to the edentulous members of the freeliving sample. The institution sample had a much higher mean intake of non-milk extrinsic sugars (77-81g/day) than the free-living sample (54-56g/day). As the numbers with natural teeth in the institution sample were small, intake data are not presented by numbers of teeth.

Plasma ascorbate values were very low in older adults living in institutions. The median value for the dentate was $31.0 \mu \mathrm{mol} / 1$, but only $11.4 \mu \mathrm{mol}$ for edentulous $(\mathrm{p}<0.05)$. No other blood analytes showed a significant relationship with dental state in the institution sample.

\section{Discussion}

This review of the major findings from the NDNS of adults aged 65 and over (Steele et al., 1998) showed that dental status in older people was associated with perceived ability to eat a number of food items, and those difficulties were reflected in the amount of fruit, vegetables, and nutrients, particularly fiber, eaten. The differences in diet by dental status in older people were also related to serum ascorbate and retinol levels.

The findings of the NDNS provided unequivocal evidence of a relationship between dental and nutritional status. Both the dental and the dietary surveys used a sound methodology and sophisticated methods of data collection. The samples were large and representative of the general population. Detailed information about the quantities of foods and nutrients consumed by the sample of elderly people were collected. In addition to a four-day weighed diary record of all food and drink consumed both in and out of the home, blood and urine samples were analyzed by the Micronutrient Status Laboratory, formerly at the Medical Research Council Dunn Nutrition Unit, Cambridge. The intake data have been corrected to eliminate high levels of micronutrient intake associated with prescribed nutrient supplements. In addition to number of natural teeth, this study assessed the relationship between number of occluding posterior pairs of teeth and outcome measures. Numbers of teeth may not be the most adequate measure of masticatory function. Having back teeth which occlude may be more relevant. The results were similar when either number of natural teeth or number of occluding posterior pairs were used as a measure of oral health. Data analysis took into account significant confounding factors, and results were adjusted for age, gender, area of residence, and social class.

Interestingly, having a functioning natural dentition defined as having more than twenty teeth increased the likelihood of having an acceptable BMI (20-25). The approach used in this study tested the relationship between oral health measures and four categories of BMI (underweight, "normal”, overweight, and obese), as it was clear that the association between number of teeth and BMI was not linear. This differs from other studies that assumed a linear association between oral health measures and relative body weight. To assume linearity may cancel or mask the true association, or alternatively, may show a weak association in either direction.

One may argue that reverse causality may explain these findings. Obese people are more likely to have a diet rich in sugar or other poor oral health habits, which in turn may explain the poor oral health. However, it is unlikely that this would explain the association between lower number of teeth and being underweight. A low BMI is easily explainable on the basis of real functional difficulties that can prevent normal eating in some cases. Furthermore, the strongest associations observed (both being underweight and obese) were where people had some teeth, but were not edentulous It can be more difficult to provide adequate function, and therefore to provide for an adequate and varied diet, where there are a few poorly distributed teeth than where there are none at all replaced by a full denture. While this does not always hold true, it may partly explain the relationships observed. Studies adopting a prospective epidemiologic design should be carried out to further elucidate this issue.

The findings of this study have important implications for public health policy. The poor 
masticators identified in this study were those with less than 21 teeth without replacement. This provides further scientific basis for the definition of an acceptable oral health as having 20 natural teeth or more (DOH, 1994). Most efforts to improve the diets of older people have been directed at health education. Relatively little attention has been paid to the impact of the teeth, which imposes dietary restrictions on older people with consequences for their nutritional status. Health promotion strategies should incorporate the need to retain a functional dentition for life to avoid diet restriction, in particular fruit and vegetables. It is obvious that overcooking raw vegetables and fruits would soften them, which would make manageable by those with fewer teeth to eat them. However, this may also reduce the amount of nutrients and fiber in the diet.

This review of the major findings from the NDNS of adults aged 65 and over provided strong evidence that maintaining a natural and functional dentition into old age, defined as having more than twenty teeth, may have an important additional role to play in having a healthy diet rich in fruits and vegetables, a satisfactory nutritional status, and an acceptable body mass index.

\section{References}

BRODEUR, J. M.; LAURIN, D.; VALLEE, R. \& LACHAPELLE, D., 1993. Nutrient intake and gastrointestinal disorders related to masticatory performance in the edentulous elderly. Journal of Prosthodontic Dentistry, 70:468-473.

CARLOS, J. P. \& WOLFE, M. D., 1989. Methodological and nutritional issues in assessing oral health of aged subjects. American Journal of Clinical $\mathrm{Nu}$ trition, 50:1210-1218.

CHAUNCEY, H. H.; MUENCH, M. E.; KAPUR, K. K. \& WAYLER, A. H., 1984. The effect of the loss of teeth on diet and nutrition. International Dental Journal, 34:98-104.

DOH (Department of Health), 1994. An Oral Health Strategy for England. London: DOH.

FINCH, S.; DOYLE, W.; LOWE, C.; BATES, C. J.; PRENTICE, A.; SMITHERS, G. \& CLARKE, P. C., 1998. National Diet and Nutrition Survey: People Aged 65 and Over. Report of the Diet and Nutrition Survey, v. 1. London: The Stationary Office.

GEISSLER, C. A. \& BATES, J. F., 1984. The nutritional effects of tooth loss. American Journal of Clinical Nutrition, 39:478-489.

HOLLISTER, M. C. \& WEINTRAUB, J. A., 1993. The association of oral status with systemic health, quality of life, and economic productivity. Journal of Dental Education, 57:901-911.

KRALL, E.; HAYES, C. \& GARCIA, R., 1998. How dentition status and masticatory function affect nutrition intake. Journal of American Dental Association, 129:1261-1269.
MOYNIHAN, P. J., 1995. The relationship between diet, nutrition and dental health: An overview and update for the 90s. Nutrition Research Review, 8: 193-224.

MOYNIHAN, P. J.; SNOW, S.; JEPSON, N. J. A. \& BUTLER, T. J., 1994. Intake of non-starch polysaccharide (dietary fibre) in edentulous and dentate persons: An observational study. British Dental Journal, 177: 243-247.

PAPAS, A. S.; PALMER, C. A.; ROUNDS, M. C. \& RUSSELL, R. M., 1998. The effects of denture status on nutrition. Special Care in Dentistry, 18:17-25.

PAPAS, A. S.; PALMER, C. A.; ROUNDS, M. C.; HERMAN, J.; McGRANDY, R.; HATZ, S.; RUSSELL, R. M. \& DePAOLA, P., 1989. Longitudinal relationships between nutrition and oral health. Annals of the New York Academy of Science, 561:124-142.

STEELE, J. G.; SHEIHAM, A.; MARCENES, W. \& WALLS, A. W. G., 1998. National diet and Nutrition Survey: People Aged 65 Years and Over. Report of the Oral Health Survey, v. 2. London: The Stationary Office.

WAYLER, A. H.; MUENCH, M. E.; KAPUR, K. K. \& CHAUNCEY, H. H., 1984. Masticatory performance and food acceptability in persons with removable partial dentures, full dentures, and intact natural dentition. Journal of Gerontology, 39:284-289.

Submitted on April 29, 2002

Final version resubmitted November 19, 2002

Approved on January 15, 2003 